\title{
Organizational Learning of Controllers and Controlled Agencies: Innovations and Challenges in Promoting Accountability in the Recent Brazilian Democracy
}

\author{
Cecília Olivieri $^{1}$, Marco Antonio Carvalho Teixeira ${ }^{2}$, Maria Rita Loureiro ${ }^{2}$, Fernando Abrucio ${ }^{2}$ \\ ${ }^{1}$ School of Arts, Sciences e Humanities, University of São Paulo, São Paulo, Brazil; ${ }^{2}$ Public Management Department, Getulio Var- \\ gas Foundation, São Paulo, Brazil. \\ Email: cecilia.olivieri@usp.br, marco.teixeira@fgv.br, maria.loureiro@fgv.br, fernando.abrucio@fgv.br
}

Received August 28 ${ }^{\text {th }}$, 2013; revised September $30^{\text {th }}, 2013$; accepted October $8^{\text {th }}, 2013$

Copyright (c) 2013 Cecília Olivieri et al. This is an open access article distributed under the Creative Commons Attribution License, which permits unrestricted use, distribution, and reproduction in any medium, provided the original work is properly cited.

\begin{abstract}
This paper analyzes a case of organizational learning in the Ministry of Social Development and Fight against Hunger. This organizational learning process was generated from demands that were external to the organization and it was possible thanks to the way in which Ministry's departments interacted with the governmental internal control agency (Office of the Comptroller General), and thanks to the Ministry's specific conditions, both organizational and contingent. This paper demonstrates that building dialogue in the process of auditing and inspection led to improvement in the control process and also in public policy management. Both the Office of the Comptroller General and the Ministry of Social Development underwent learning processes. Office's analysts needed to learn the working and implementation logic of a new policy in social development area (the Unified Social Welfare System), and the Ministry employees needed to produce rules and administrative procedures to support the inspection, as well as review concepts and procedures involved in Ministry's relationship with municipalities.
\end{abstract}

Keywords: Organizational Learning; Governmental Internal Control Agency; Auditing and Inspection

\section{Introduction}

The goal of the research from which this paper originated was to analyze the impact of the Brazilian government's agency in charge of internal control on public policy management. The investigation was guided by two dimensions: promoting both governmental accountability and efficiency in public policy implementation. The research's theoretical frameworks therefore came from literature on political accountability and on governmental controls, examining how institutional arrangements work to hold politicians and bureaucrats accountable for the results of public policies [1].

One of the unexpected results, however, was identified as an abundant process of organizational learning, which we describe in this paper, and for which analysis we turn to the theoretical framework of [2].

In this introduction, we briefly describe the recent transformations undergone by the Brazilian political and administrative system and highlight the advances in social areas, given that our analysis covers the relationship between the controlling agency and the Ministry in charge of social welfare policies.

The Brazilian political system has endured profound institutional transformations since the country's redemocratization and approval of the democratic Constitution of 1988. As of then, our press is free, our political parties compete and our elections are regular and fair in Legislative and Executive Powers at all three levels of government: federal, state and municipal ${ }^{1}$. In addition, popular participation mechanisms were broadened and deepened through collegiate forums such as councils and conferences, and institutions promoting transparency and accountability of governmental actions were strengthened.

In the areas of education, health and social welfare, the restructuring and broadening of public policies, in accordance with the constitutional principles of universal and free service, were a great deal responsible for the social

${ }^{1}$ Brazil is the only federative country in the world with three levels of politically autonomous government levels, as per article $1^{\text {st }}$ of the 1988 Constitution. 
advances of the last 20 years, which promoted social inclusion of a large contingency of people until then not attended by public services.

Despite such improvement, there are still many challenges to overcome in order to consolidate Rule of Law in the country. In the field of public safety and guaranteeing human rights, for instance, we must progress in eradicating police violence against the poorer population. In the judicial arena, we must increase people's access and reduce the duration of litigations. In politics, we are still struggling with corruption and clientelism practices in dealing with public goods.

In this paper's specific case of interest, there are two institutional advancements in the Brazilian democratic order that are worth noting. First, the institutionalization of the system of checks and balances, encompassing not only the traditional agencies of external control, such as the Brazilian Court of Audit (TCU-Tribunal de Contas da União), but also creating a new agency that centralizes internal control of federal public administration, the Office of the Comptroller General (CGU_Controladoria Geral da União), which became the Executive Power's agency in charge of policies for promoting transparency and fighting corruption. The second advancement involves the creation of new governmental agencies in charge of social policies, such as the Ministry of Social Development and Fight against Hunger (MSD-Ministério do Desenvolvimento Social e Combate à Fome), and the reorganization of social welfare programs, which explain the improvement of social indicators on one hand and, on the other, suggest the existence of organizational learning and innovation processes.

MDS was created in 2004, in the second year of the Lula administration, with the purpose of integrating policies for social welfare, hunger combatting and income transference. Its main programs are currently the Family Allowance Program (PBF-Programa Bolsa Família) and the Unified Social Welfare System (SUAS—Sistema Único de Assistência Social).

$\mathrm{PBF}$ is an income transference program for families in vulnerable situations, and which seeks to increase family access to basic social rights by means of the imposed conditions for continuing to receive the benefit: children are required to attend school and family members are required to present themselves at health and social welfare offices. It was launched in 2003, as a result of the Lula administration's strategy of centralizing the existing poverty reduction policies, characterized by fragmentation and weak results. Over the last years, the program's management mechanisms were improved (such as the Cadastro Único-Single Enrollment, an informatized system of enrolling current and future beneficiaries), presently counting over 20 million low-income families, of which 13.4 million receive PBF.
In addition, PBF requires a great deal of political and institutional articulation, as it is jointly executed by the three federative levels. The federal government is responsible for resources and regulation, and the states and municipalities for selecting beneficiaries (according to federal directives), for enrolling them in the system and for monitoring their compliance with the imposed conditions. In this way, the Cadastro provides all three government levels with information, new due to its scope and up-to-date status, on the social and economic conditions of benefited families (housing, sanitation, income, employment etc.) and on their access to the services set forth as imposed conditions in education, health and social welfare [3].

In the case of education, there are approximately 17 million children and teenagers in PBF with school attendance being monitored. Most (86.67\%) attend elementary school, which corresponds to $40 \%$ of all enrollments at that level of schooling. Regarding the imposed conditions in the field of health, approximately 6 million children (up to the age of 7) and 14 million women (from 14 to 44 years of age) are served. In social welfare, the Child Labor Eradication Program (PETI-Programa de Erradicação do Trabalho Infantil) covers over 800 thousand beneficiaries, of which approximately $90 \%$ are in the PBF public. Given that many families have beneficiaries monitored in more than one field, there are millions of citizens served by health, education and social welfare policies in a priority manner [3].

SUAS was structured from 2005 onwards, by MDS, as a way of overcoming the former standard of providing social services (characterized by the philanthropic nature of the activities and by clientelism practices) and one of its main goals is to organize social services into a network of protection for families benefited by income transference programs. It is a decentralized system of producing social welfare actions, structured as determined by the new Organic Law of Social Welfare (LOAS-Lei Orgânica de Assistência Social, of 1993), which is deemed a great advancement for defining social welfare as a right of the citizen, and not as charity. Among its principles are transparency and universal access to the social welfare benefits, services and programs, and its implementation strategy essentially involves cooperation between the three federative levels, since the federal government is in charge of financing and regulating the service and the states and municipalities are in charge of its financing and execution.

As previously indicated, these recent initiatives by democratic governments in Brazil have considerably improved social conditions in the country. Although there are still almost 40 million Brazilians living in poverty conditions-20\% of the country's population, since 2001 
the income of the poor grew almost three times more (8\%) than the national average (2.7\%) and almost four times more than that of the rich (1.5\%) and social inequality - one of the highest in the world-began to slowly fall: the Gini index decreased from 0.535 in 2004 to 0.509 in 2009 [4]. Most of the responsibility for this reduction is attributed to employment revenues and salaries (66\%), but the income transference programs, headed by the Bolsa Família, contributed with 17\%, a greater proportion than traditional welfare benefits which contributed approximately 15\% [5].

This paper seeks to examine the organizational learning processes resulting from the relationship established between CGU and MDS. Such approach is quite innovative in this area of Brazilian public administration, not just because of the focus on relationships between governmental management and control, but equally from the point of view of organizational studies.

The following text is thus organized: initially we present the characteristics of the Brazilian system of checks and balances and the role of CGU in promoting governmental accountability and transparency; in the second part, we analyze documents related to SUAS implementation and inspections, and data obtained in interviews with employees directly involved in inspections from CGU and the National Secretariat for Social Welfare (SNAS-Secretaria Nacional de Assistência Social). Analysis of the relationship between CGU and MDS's SNAS allowed for a discussion of the factors that promoted or hindered organizational learning in those agencies. Such learning may be defined as a double-loop, since SNAS altered rules and procedures of the SUAS implementation process. There are also suggestions of deuterolearning process, given that SNAS intends to create its own mechanisms of inspecting public policies, with the purpose of producing information on the SUAS implementation that may be useful in new processes for improving policy management.

Among the results of this analysis, we have found that factors promoting organizational learning included the collaboration relationship established between CGU analysts and SNAS employees during the inspection process and certain institutional and political traits of MDS, among which its low level of institutionalization, the availability of high-level personnel and their openness to the culture of public policy evaluation. Special merit may be attributed to this Ministry's privileged position before others, given its responsibility for implementing a program, Bolsa Família, it is essential to ensure political legitimacy for the President of the Republic.

In our conclusions, we indicate that CGU's work promotes organizational learning in the public agencies, it inspects factors such as those agencies' low level of institutionalization, the relative weakness of corporative interests from its bureaucracy or from social groups related thereto and CGU's own work seems to have accelerated the learning process.

\section{CGU in the Brazilian Governmental Accountability System and Municipality Monitoring}

The control of government is one of the normative requirements for proper functioning of representative democracy and public bureaucracy; therefore, it is expected that government agents' actions and the results of their policies be liable to permanent monitoring and sanctions. The actions of elected politicians, appointed high-level managers and career employees must be subjected to inspection mechanisms. Thus, the institutions created to ensure control of the government are based on the checks and balances between the Powers: these are independent, but must mutually control one another to avoid power abuse and to promote exercise of the government publicly and for the public ${ }^{2}$.

In Brazil, the 1988 Constitution reinforced the power of control agencies as guardians of legality and probity in public management, slowly unleashing modernization processes in their internal organizational structures aiming at better qualifying them for their constitutional attributions. Several agencies and entities are in charge of controlling Brazilian Federal Public Administration (FPA), forming a complex system. According to article 70 of the Federal Constitution, control is divided into external and internal. The former is exercised by the National Congress and the latter by "the internal control system of each Power", with the CGU centralizing such system in the Executive Power. National Congress relies on the Brazilian Court of Audit (TCU) for external control, which corresponds to the "accounting courts" model.

Working in parallel to these agencies directly occupied with monitoring and audit activities are institutions that participate in other steps resulting of the monitoring and aud it processes, especially in cases where irregularities and frauds are uncovered, such as police investigation and criminal prosecution, which befall to the Federal Police, the Public Prosecutor's Office and the Judicial Power'.

\footnotetext{
${ }^{2}$ As per [6], control of government agents is a crucial dimension of a democratic order: "If men were angels, no government would be necessary. If men were ruled by angels, the government would not need internal and external controls. Dependence upon the people is undoubtedly the primary control on the government, but experience has taught humankind that additional precautions are necessary".

${ }^{3}$ Recent studies have shown significant transformations in the country's control agencies since redemocratization, such as the courts of audit ([7,8]), and have equally highlighted the political role played by others, such as the Public Prosecutor's Office [9] and the Federal Secretariat of Internal Control [10].
} 
As control institutions were strengthened, the administrative reforms undergone by the country during the 1990s also placed the issues of public policy managerial efficiency and performance in the national agenda. Control agencies, especially TCU and CGU, took on supporting (and sometimes leading) roles in demanding public policy compliance with the principles of legality, probity and efficiency. Recent studies suggest that inspection and auditing processes carried out by control agencies ended up working as powerful instruments to promote transparency, accountability and quality in public management.

CGU gained enormous relevance in the last years due to the increase in its inspection and auditing activities and to the new association of said activities with processes of promoting transparency and quality in public management. These changes are due to the internal control system restructuring process, initiated with the creation of the Federal Secretariat of Internal Control (SFCSecretaria Federal de Controle Interno) in 1994 and consolidated with the creation of CGU in its current format in 2003.

CGU was created in 2002, as Office of Internal Affairs (Corregedoria), and in 2003 it was changed to Office of the Comptroller General. Since then, it has been within the structure of the Republic's Presidency, thus occupying a supervision position with regard to the Ministries, and is responsible for technical supervision and normative guidance of the four agencies that comprise the federal government's integrity systems:

- Federal Secretariat of Internal Control, in charge of the Internal Control System,

- Office of Internal Affairs, through the Corrections System,

- Office of the Ombudsman-General (Ouvidoria Geral da União), through the ombudsman units, and

- Secretariat for Preventing Corruption and Strategic Information, through the function of preventing and fighting corruption in the Executive Power.

The Federal Secretariat of Internal Control carries out activities of evaluating government program executions and verifying legality of budget, asset and financial management of the Federal Executive agencies. Decentralized control actions, or monitoring use of federal funds by the state and municipalities, are carried out by Regional Comptroller Offices (CRU-ControladoriasRegionais da União), which are CGU agencies existing in all states of the federation.

The Office of Internal Affairs supervises investigation of responsibilities for managers' administrative irregularities in the Federal Executive agencies, application of the corresponding sanctions and replacing any losses to the public treasuries. The Office of Internal Affairs is responsible for the activity of correction, that is, to repress and prevent losses to public assets by means of investigations, inspections and disciplinary administrative procedures to verify the responsibility of public agents.

The Office of the Ombudsman-General regulates and organizes ombudsman activities in the Federal Executive, and receives citizen manifestations on the rendering of public services, directing them to the responsible agencies and seeking solutions for the issues presented.

The Secretariat for Preventing Corruption and Strategic Information aims to promote transparency in public management and develop preventative projects to inhibit and dissuade corruption.

CGU is, therefore, the Brazilian federal government agency that centralizes internal control of public administration, carrying out inspection and auditing activities of all its agencies and including agencies from other federative levels, such as states and municipalities, when these receive federal funds. In the last two decades, the volume of federal resources transferred to municipalities has grown, especially for executing federal public policies in social areas. As most Ministries do not have structures dedicated to monitoring and evaluating public policies, CGU's work has been an important instrument in verifying the execution of such federal funds transferred to municipalities.

Based on such inspection and auditing, CGU produces reports on the execution of governmental programs that promote a level of transparency previously unheard of in Brazilian public management, and proposes organizational changes to the inspected agencies, aiming at increasing the efficiency of public policy implementation and therefore of management quality.

Audits are carried out in two stages: the first occurs in Brasília, when the CGU team goes to the Ministry to analyze the aspects of the federal program through which federal funds are transferred to municipalities; the second occurs in the municipalities receiving federal funds, inspected by the CGU analyst teams that work in the states. Given the unfeasibility of inspecting the over $5500 \mathrm{mu}-$ nicipalities, they are selected by lottery, and approximately 200 municipalities are selected each year. Up to 2009, approximately 1800 municipalities were inspected, which corresponds to $32 \%$ of the total. In this way, CGU builds an evaluation of policy operations not only at the ministerial level (on the policy management instruments at the federal level), but also at the implementation level, that is, in the municipalities, analyzing how the resources are actually used. CGU's analyses on policy implementation in municipalities are sent to the corresponding Min- 
istry, so that it can the usually necessary measures regarding adjustments in regulations and correcting problems, frauds or inefficiency.

CGU's reports on inspecting federal policies in municipalities are published in CGU's website and constitutes one of the first Brazilian experiences of public disclosure of federal government activities with great repercussion in the media and among those involved (the municipalities). Actually, disclosing the reports was part of the inspection program's own strategy. Its purpose was not only to publish state actions, but also to generate among the unselected/uninspected municipalities a willingness to manage federal funds with more efficiency and probity, in face of their apprehension at becoming the object of inspection activities. In any case, disclosing such reports bears fruit such as transparency (in this case, CGU's inspection activities and the management activities of the inspected municipalities) and generation of information that is relevant from the point of view of social control (society obtained access to documents with information on the public management of their municipality, not divulged by their corresponding executive governments) and from the point of view of scientific knowledge (several academic papers were based on the data series supplied by the reports) ${ }^{4}$.

Finally, it is important to note that the information generated in these CGU inspections had never been produced, in most cases, even for the Ministries that implement the inspected federal policies, since most of them do not have a system for monitoring their own policies. This is the case of the Ministry of Social Development, which is in charge, as mentioned, for implementing the federal governments social welfare policy and has as one of its goals to restructure social welfare policy in states and municipalities. It does this by means of regulating welfare actions and transfer of resources for such actions to be carried out by municipal public agents or private agents hired by the municipalities.

\section{Organizational Learning from Inspection and Auditing Processes: The Case of the Ministry of Social Development}

The exchange between the MDS's National Secretariat

\footnotetext{
${ }^{4}$ Examples of papers based on data from CGU's reports: Analysis of irregularities in FUNDEF's municipal administration: verifications of the inspection program by public lotteries by the Office of the Comptroller General (Marcos Mendes, Transparência Brasil, 2004); Exposing Corrupt Politicians: The Effects of Brazil's Publicly Released Audits on Electoral Outcomes (Ferraz, C. and Finan, F., Quarterly Journal of Economics, 2009), Electoral Accountability and Corruption: Evidence from the Audits of Local Governments (Ferraz, C. and Finan, F., American Economic Review, 2010), and Law Enforcement and Local Governance in Brazil: evidence from random audit reports (Zamboni Filho, Yves and Stephan Litschig, Mimeo, 2006).
}

for Social Welfare (SNAS) and CGU began in 2004, when the basic rules for the Unified Social Welfare System (SUAS) were being prepared. SUAS articulates means, efforts and resources to execute social welfare programs, services and benefits, thus organizing the supply of social welfare in all of Brazil, promoting social protection and well-being to families, children, teenagers and youths, people with disabilities, senior citizens-in short, to all who need it. One of SUAS' main regulations are the Basic Operational Rules (NOB/SUAS-Normas Operacionais Básicas), which govern the System's decentralized administration, the relationship between the three government levels and how public resources are applied.

Since SUAS was a new and recently implemented policy, CGU began to require that the Ministry send the program's more detailed regulations, based on which it would inspect the municipalities. In such monitoring processes, meetings are required between CGU analysts and managers from the Ministries in charge of the inspected program, mainly in two moments: the first occurs before the municipalities are inspected so that CGU can learn the characteristics of the policy as designed by the Ministry. The second moment of interaction between CGU and the Ministry occurs after inspection and involves the Ministry's validation of the report prepared by CGU. In this second phase, discussions are often deeper and more conflicted, for they involve defining the recommendations the Ministry must follow to correct the program's gaps and inefficiencies found by CGU's inspection. Since CGU annually holds new lotteries and inspects new municipalities (those previously selected may be drawn again), the recommendations of the previous year's report and whether or not they were implemented are discussed each year, which is another source of potential divergence between the Ministry and CGU.

In the case of SUAS, the relationship between CGU and the Ministry became a quite close "two-way street": it meant learning for both CGU analysts and SNAS managers. This sort of relationship is very rare, for in most cases the Ministry is deeply resisting of the recommendations put forth by the controlling agency and the latter is reluctant to alter its internal auditing processes to the programs' particulars.

According to the interviewees, this relationship meant a very fruitful interaction and a great learning process for MDS and CGU. Although it was not an entirely harmonious process, since there were conflicts and disagreements, it ended up producing cooperative relationships, in which both parties (CGU analysts and Ministry managers) sought to build understanding and pursue the common goal of promoting quality in the SUAS implementation. 
The interactions between CGU and SNAS generated mutual efforts to understand the demands and form of working of each institution, allowing for organizational changes especially in MDS. CGU analysts demanded that SNAS prepare regulations on the program's specifics and service production indicators so that they could inspect the municipalities. This required SNAS to seek qualification to produce the information and to create a specific team to deal with matters and proceedings related to inspection. This team is occupied with receiving and centralizing the demands of the controlling agencies (CGU and TCU), distributing them within the Ministry to prepare the response, collecting information from the municipalities about the problems identified in the inspection and responding to the controlling agencies. SNAS, on the other hand, demanded that CGU analysts understand the SUAS specifics and the new logic of rendering social welfare services and consequently accepted new forms of service inspection.

It is important to note that this learning process is not set forth in CGU's inspection rules. It arose from practical experience, by means of building room for dialogue in the inspection process, greater in scope than that set forth in the rules. Although there are mandatory meetings to be held between the CGU and Ministry teams, in the SUAS case this required greater mutual willingness and understanding. And it depended not only on holding the joint meetings foreseen in the rules, but also on building a relationship of mutual understanding over the years. This relationship was not set forth in the formal rules, and its creation and effectiveness relied on the reciprocal will and willingness of the actors involved.

Through such a dialogue, a reciprocal organizational learning process can be experienced: the auditors learned about the SUAS regulations and parameters, which are different from those established in other social policies; on the other hand, the managers learned more about their own policy in their effort to present the program's logic and characteristics and justify their choices before the CGU analysts.

The analysts' learning occurred in single-loop, in that they did not review their working procedures and rules, but merely took the policy's specifics and the structure of the Ministry in question into consideration in the inspection process. Although they spent more time in the SNAS audit than usual, this did not entail revising their working procedures or instruments.

The MDS managers' learning, on the other hand, occurred in double-loop, and may be described in three dimensions: creating regulations, restructuring procedures for policy implementation and organizational restructuring. Let us look at each of these learnings more closely.
MDS' first learning dimension-the creation of SUAS regulations by SNAS - ensued in good part from CGU's demands for more detailed rules about the program's execution, in order to inspect it in the municipalities. In this way, CGU forced the Secretariat to define regulations (ordinances, decrees, law projects) with greater speed than it thought necessary. MDS interviewees reported that they always perceived CGU as very interested, requiring information on the program's functioning to be able to perform the monitoring in the field and reading the Ministry's documents to be able to guide municipalities in implementing the new policy.

Naturally, CGU's attribution of requiring that the program rules be clearly defined was initially felt as an encumbrance by the managers, for it demanded that they respond in a timeframe that was different from the one defined or desired by the managers. They slowly understood the importance of such requirements to qualify the program itself. One factor mentioned by the interviewees for the good relationship in this process was maintaining the same leader in the CGU team of analysts during all years of the program's closer inspection, thus ensuring that the knowledge accumulated during the learning process was not lost.

The second dimension of MDS' learning involved the restructuring of the policy's implementation procedures. As CGU pointed out problems in SUAS implementation in municipalities, SNAS had to revise the regulations and the incentive and control mechanisms over the municipal executive powers. Since most Brazilian Ministries do not have their own systems of monitoring and evaluation, the information produced by CGU in monitoring the municipalities are essential for the Ministries that implement programs in a decentralized manner to know what happens at the other end of the system.

These requirements initially caused a good deal of stress at SNAS, for it needed to interrupt its working routine to prepare responses to CGU's demands. Over time, the managers realized that CGU's demands brought MDS important information about the program's execution that would otherwise not reach the Ministry. In this way, they began to see that the information produced by the CGU audits helped MDS to have a general view of the policy's functioning and of its problems on a national scale, and therefore helped the Ministry to improve the program's management quality.

In addition, since CGU analysts are "external" agents for the Ministry and therefore have an "outside" view, they can help the managers to identify gaps not foreseen by the policymakers. This difference in perspectives may generate many divergences and some conflict between analysts and managers, but it can also be a source of mutual learning. This occurred in the issue of local level 
government corruption and the Ministry's responsibility for controlling the municipalities that receive transfers. Initially, the managers thought that CGU analysts worried far too much about frauds. Indeed, CGU analysts are biased to identify gaps and errors, while managers prioritize the policy's functioning, assuming those involved will adhere to legal principles and regulations.

As reported by an MDS interviewee, however, it was only after the CGU inspections that he realized the "municipalities are not always honest". This means that the Ministry must indeed worry about irregularities that may occur in the program's execution. Creating a new and well-meaning policy is not enough; there is also need for monitoring, control and punishment mechanisms. This generated a clear perception on the part of the managers of the importance of CGU's work, thus changing their initial standing on the agency's work. This relevance occurs not only in identifying and correcting irregularities, but also contributes to improve the policy's quality at the Ministry, state and municipal levels.

Finally the third dimension of learning for MDS occurred at the level of organizational changes. CGU's demands ensuing from inspecting the municipalities required the Secretariat to qualify itself in order to interact with the controlling agencies, and, for that purpose, SNAS created a specific team to deal with matters related to inspection. This team receives and centralizes demands from the controlling agencies, distributes them within the Ministry to produce responses and collects information from the municipalities about the problems identified in the inspection. In fact, the Secretariat established a specific office dedicated to handling all matters related to inspection and interactions with all SNAS departments. Creation of this office helped improve the directives defined by the Secretariat regarding municipalities. It was in this process that CGU's work led SNAS to qualify itself considering both the program's management (more clearly defining its implementation rules) and its internal organization (structuring a team and specific procedures to organize responses to the controlling agencies).

Interviewees highlighted that in this process of creating new structures and the corresponding need for more employees and resources, CGU's demands helped the Secretariat to require institutional support from the Ministry in the form of organizational resources, in order to fulfill the goals of the policies and programs and respond to the controlling agencies' demands. In other words, CGU's audits became a support for managers to demand from their superiors the necessary resources, such as personnel hiring and institutional reorganization, in order to solve problems in the policy's execution. This can be seen as a singular aspect of this organizational learning experience: one external organization encourages another to learn and as a result of such learning there is a change in its own structure.

In the MDS case, there was another fact in its favor: that the Ministry managed the Bolsa Família, one of the most important social programs of the Lula administration and responsible for a significant part of the then President's political legitimacy and high popularity, according to opinion surveys made in the country. For this reason, this Ministry had greater ease in obtaining financial resources and hiring qualified personnel. Among the employees brought to MDS and SNAS were members of the career of Specialists in Public Policy and Governmental Management, known as EPPGG (Especialistas em Políticas Públicas e Gestão Governamental). This career was created in the 1990s for the purpose of supplying the federal government with highly qualified personnel, specialized in management, without being permanently allotted to a specific Ministry. Since they may be requested by any Ministerial office, they are very disputed. Another trait of members of this career is that they perceive public policy evaluation as an essential factor for the quality of state work, which concept is relatively new and little disseminated in the country [11]. Given the administration's priority for social policies, MDS was able to recruit several EPPGGs, which reinforced its management capacity.

Finally, it is important to note the likelihood of more organizational changes occurring, for MDS intends to create a specific agency to develop and manage the SUAS internal monitoring processes. In other words, the Ministry wishes to produce internally the information that CGU currently produces through municipality monitoring, which will require the creation of new structures and processes. MDS this intends to ensure that it controls the production of information that is essential to the efficiency of its policy implementations.

To sum up, the concrete results of these learning processes were improvement of SUAS management and of CGU's audits. The elements needed for this learning to occur were:

- Joint meetings between analysts and managers to discuss SUAS inspection aspects.

- Willingness of professionals to understand the view and position of their counterparts from the other institution.

- Availability for building the relationship of understanding (primarily by maintaining the inspection and secretariat team leaders in their respective positions), so as to ensure that individuals' acquired knowledge would stay in the organization.

- Low institutionalization of SUAS and MDS, which were created less than 10 years ago and are being 
structured (which implies the need for establishing rules and agencies and, at the same time, the lack of crystalized practices and institutions).

- MDS' privileged position regarding other Ministries in the "competition" for organizational resources.

The first three elements refer to traits that can be promoted and disseminated by means of creating organizational incentives to such behavior. The last two elements, on the other hand, are contingent factors that cannot be repeated at other organizations, and which absence increases the need to reinforce organizational incentives.

The main element that hindered learning in this case was the divergence of views between CGU analysts and MDS managers, which took time to be reduced. It is, to some extent, a natural factor in the life of organizations, which create their own culture and vision regarding their work.

Finally, this learning process may be leading to the creation of a deuterolearning process, since MDS intends to create its own structures for monitoring its policies. Monitoring activity by MDS tends to generate information and capacity for the Ministry to, by itself, identify policy gaps and correct them, and the evaluation processes may become instruments through which the organization learns to learn [12].

\section{Conclusions}

In the analyzed case, organizational learning was generated from demands that were external to the organization (CGU's inspection in SUAS) and it was possible thanks to the way in which CGU and MDS interacted (joint meetings with the purpose of seeking understanding) and to MDS' specific conditions, both organizational and contingent.

This paper demonstrates that building a dialogue in the process of auditing and inspection led to improvement in the control process and in public policy management. Both CGU and MDS underwent learning processes. CGU analysts needed to learn the working and implementation logic of a new policy such as SUAS, and MDS employees needed to produce rules and administrative procedures to support the inspection, as well as review concepts and procedures involved in MDS' relationship with municipalities.

On the part of MDS, the learning was adapting itself in order to be able to precisely define the information needed for the program's implementation and inspection; on the part of the control agents, it was understood as a new policy, with a new dynamic and new form of implementation. There were conflicts in that process, for the views of MDS and CGU did not always coincide or easily fit together. But, over time, both parties were educated, and room for understanding was built and could be
Table 1. Organizational learning in new public agencies in democratic Brazil.

\begin{tabular}{|c|c|}
\hline CGU Learning (single loop) & SNAS/MDS Learning (Double loop) \\
\hline $\begin{array}{l}\text { - Learning about the } \\
\text { particulars of the inspected } \\
\text { policy and the structure of } \\
\text { the Ministry in charge of it. }\end{array}$ & $\begin{array}{l}\text { Creation of new regulations } \\
\text { pertaining to execution of SUAS. } \\
\text { Restructuring of the policy's } \\
\text { implementation processes, } \\
\text { especially mechanisms of } \\
\text { incentive and control over } \\
\text { municipal executive powers. } \\
\text { Organizational changes: creation } \\
\text { of a team to handle matters related } \\
\text { to inspection. }\end{array}$ \\
\hline
\end{tabular}

used to discuss new programs. The history of dialogue and building understanding makes it easier, for both sides, to build new understandings.

Table 1 summarizes the learning processes described above.

\section{REFERENCES}

[1] C. Olivieri, L. Abrucio, M. A. Teixeira, M. R. Loureiro and V. Oliveira, "The CGU and the Federal Public Administration (FPA) in the Brazilian System of Democratic Control: Evaluation of the Institution and the Actors' Perception,” Research Report, 2011.

[2] C. Argyris and D. Schön, “Organizational Learning II: Theory, Method and Practice,” Addison-Wesley, Reading, 1996, 305 p.

[3] L. Abrucio and A. Licio, “Contribuições e Oportunidades do Programa Bolsa Família para as Políticas Sociais no Governo Lula,” 2012.

[4] IBGE, Instituto Brasileiro de Geografia e Estatística. Pesquisa Nacional de Amostra Domiciliar (PNAD), 2009.

[5] M. Neri, “A Nova Classe Média: O lado Brilhante da Base da Pirâmide,” 1st Edition, Editora Saraiva, Rio de Janeiro, Vol. 1, 2011, 311 p.

[6] N. Bobbio and O. Futuro da Democracia, "Uma Defesa das Regras do Jogo,” Paz e Terra, Rio de Janeiro, 1992.

[7] B. Speck, "Inovação e Rotina no Tribunal de Contas da União,” Konrad Adenauer Stifung, São Paulo, 2000.

[8] M. R. Loureiro, M. A. Teixeira and T. C. Moraes, "Democratização e Reforma do Estado: O Desenvolvimento Institucional dos Tribunais de Contas no Brasil Contemporâneo,” Revista da Administração Pública, Rio de Janeiro, Vol. 43, No. 4, 2009, pp. 739-772.

[9] R. Arantes, "Ministério Público e Política no Brasil," Sumaré/Educ. Public Ministry and Politics in Brazil, São Paulo, 2002.

[10] C. Olivieri, “A Lógica Política do Controle Interno-O Monitoramento das Políticas Públicas no Presidencialismo Brasileiro,” São Paulo, Ed Annablume, 2010.

[11] R. Cruz, "Carreiras Burocráticas e suas Transformações: O Caso dos Gestores Governamentais no Brasil,” In: M. 
Promoting Accountability in the Recent Brazilian Democracy

R. Loureiro, L. Abrucio and R. Pacheco, Eds., Burocracia e Política no Brasil Contemporâneo, FGV, 2009.

[12] K. M. N. Calmon, “A Avaliação de Programas e a Di- nâmica da Aprendizagem Organizacional,” Planejamento e Políticas Públicas, IPEA, No. 19, 1999. 